University of Nebraska - Lincoln

DigitalCommons@University of Nebraska - Lincoln

\title{
Oxidative metabolism in plant/bacteria interactions: characterization of the oxygen uptake response of bacteria
}

\author{
C. Jacyn Baker \\ United States Department of Agriculture, jacyn.baker@ars.usda.gov \\ Norton Mock \\ United States Department of Agriculture \\ Kenneth L. Deahl \\ United States Department of Agriculture \\ Bryan Bailey \\ United States Department of Agriculture \\ Daniel P. Roberts \\ United States Department of Agriculture, dan.roberts@ars.usda.gov
}

Follow this and additional works at: https://digitalcommons.unl.edu/usdaarsfacpub

Part of the Agricultural Science Commons

Baker, C. Jacyn; Mock, Norton; Deahl, Kenneth L.; Bailey, Bryan; and Roberts, Daniel P., "Oxidative metabolism in plant/bacteria interactions: characterization of the oxygen uptake response of bacteria" (2001). Publications from USDA-ARS / UNL Faculty. 334.

https://digitalcommons.unl.edu/usdaarsfacpub/334

This Article is brought to you for free and open access by the U.S. Department of Agriculture: Agricultural Research Service, Lincoln, Nebraska at DigitalCommons@University of Nebraska - Lincoln. It has been accepted for inclusion in Publications from USDA-ARS / UNL Faculty by an authorized administrator of DigitalCommons@University of Nebraska - Lincoln. 


\title{
Oxidative metabolism in plant/bacteria interactions: characterization of the oxygen uptake response of bacteria
}

\author{
C. JAGYN BAKER ${ }^{1 *}$, NORTON MOGK ${ }^{1}$, KENNETH L. DEAHL ${ }^{2}$, BRYAN BAILEY ${ }^{3}$ and \\ DANIEL P. ROBERTS ${ }^{4}$ \\ ${ }^{1}$ Microbiology and Plant Pathology Laboratory, ARS, United States Department of Agriculture, Beltsville, MD 20705, U.S.A., \\ ${ }^{2}$ Vegetable Laboratory, ARS, United States Department of Agriculture, Beltsville, MD 20705, U.S.A., ${ }^{3}$ Alternate Crops and Systems \\ Laboratory, ARS, United States Department of Agriculture, Beltsville, MD 20705, U.S.A. and ${ }^{4}$ Sustainable Agriculture Systems \\ Laboratory, ARS, United States Department of Agriculture, Beltsville, MD 20705, U.S.A.
}

(Accepted for publication June 2001 and published electronically 5 September 2001)

\begin{abstract}
An increase in oxygen uptake has been previously described in plant cell suspensions treated with bacteria or bacterial elicitors. These studies, regarding oxygen uptake, have all been undertaken from the perspective of the host plant cell reacting to the invading pathogen. In contrast, here we describe and characterize an increase in oxygen uptake by bacterial cells in response to plant suspensions or autoclaved plant cell filtrates. Autoclaved plant cell filtrates stimulated bacterial oxygen uptake by as much as sevenfold within a few minutes after addition. This oxygen uptake response was proportional to both the concentration of the plant cell filtrate and the concentration of the bacteria. KCN inhibited the bacterial response, suggesting that bacterial respiration may be involved. Unlike the plant oxygen uptake response to bacteria, there was no concurrent $\mathrm{H}_{2} \mathrm{O}_{2}$ accumulation and the NADPH oxidase inhibitor, DPI, had no effect on the bacterial response. Streptomycin, an inhibitor of bacterial protein synthesis, inhibited the bacterial oxygen uptake response to the plant cell filtrate. K-252, a protein kinase inhibitor that strongly inhibits the plant oxygen uptake response to bacteria, had no effect upon the bacterial oxygen uptake response. When potato/bacterial cell suspensions were pretreated with either streptomycin or K-252, the combined plant/bacterial oxygen uptake response was inhibited by 15 or $70 \%$, respectively. This indicates that as much as $15-30 \%$ of the increased oxygen consumption during plant suspension cell/bacteria interactions may be attributable to bacteria, which comprise less than $1 \%$ of the total cell mass.
\end{abstract}

Keywords: Pseudomonas syringae pv. syringae; Solanum tuberosum cv. Kennebec; oxygen uptake; bacterial respiration; plant/pathogen interactions.

\section{INTRODUCTION}

Previous studies have shown that an increase in oxygen uptake occurs when plant suspension cells come into contact with bacteria or pathogen-derived elicitors. $[1,3,5,12]$. The main goal of these studies was to monitor the responses of plant cells to pathogens. The current study was undertaken to determine the possible contribution of bacterial oxidative metabolism to the plant/bacteria interaction. This is the first report, which

* To whom all correspondence should be addressed. E-mail: bakerc@ba.ars.usda.gov

Abbreviations used in the text: ACF, autoclaved plant cell filtrate; DPI, diphenyleneiodonium chloride; HK-bacteria, heat killed bacteria; K-252, a protein kinase inhibitor; KCN, potassium cyanide; LDC, luminol-dependent chemiluminescence; ROS, reactive oxygen species.

Mention of a trade name, proprietary product, or vendor does not constitute a guarantee of the product by the USDA and does not imply its approval to the exclusion of other vendors that may also be suitable. we are aware of, to characterize an oxygen uptake response by bacteria in response to plant cells or plant constituents. The focus of this study is the first phase response which is considered non-specific and occurs with compatible, incompatible and saprophytic interactions. The existence and apparent magnitude of the response (15-30\% of the plant response) is somewhat surprising in that the cell mass of the bacteria is less than $1 \%$ that of the plant cells. The bacterial response is important when considering the overall plant/microbe interaction for several reasons including: (1) at inoculum concentrations greater than $10^{8} \mathrm{cfu} \mathrm{ml}^{-1}$, the oxygen uptake by bacteria could significantly compete with plant processes requiring oxygen at critical times; (2) the uptake response signifies bacterial recognition of a change in environment and could possibly lead to bacterial gene regulation; (3) the increased oxidative metabolism and associated reactants will add to the oxidative environment with which the plant must cope. 


\section{MATERIALS AND METHODS}

\section{Chemicals}

All chemicals were purchased from Sigma-Aldrich Chemicals, Inc. (St. Louis, MO, U.S.A.) with the exception of K-252, which was purchased from Fluka Chemical Corp. (Rohkonkoma, NY, U.S.A.). Diphenyleneiodonium chloride (DPI) and K-252 were dissolved in DMSO and added to final concentrations of 10 and $1.6 \mu \mathrm{M}$, respectively. Final concentrations of DMSO were less than $0.01 \%$ and had no measurable effect on bacterial or plant cells. Streptomycin sulfate, an inhibitor of protein synthesis, was prepared in deionized water, with a few drops of $6 \mathrm{~N} \mathrm{NaOH}$ to aid solubility (titrated to $\mathrm{pH} 6$ with $\mathrm{HCl}$ ), and routinely used at a final concentration of $200 \mu \mathrm{g} \mathrm{ml}^{-1}$. KCN was dissolved in $50 \mathrm{mM} \mathrm{MES,} \mathrm{pH} \mathrm{6,}$ and used at a final concentration of $1 \mathrm{~mm}$.

\section{Bacteria}

Pseudomonas syringae pv. syringae 61 (incompatible with potato and tobacco), Ralstonia solanacearum (compatible on potato, incompatible on tobacco), Pseudomonas putida WT and J-1M (both saprophytic on potato or tobacco) [8] were grown for $20 \mathrm{~h}$ on Kings B agar plates, washed, centrifuged and resuspended in $50 \mathrm{~mm}$ MES buffer, pH 6 [1]. Plates with $P$. syringae and $P$. putida were augmented with 25 and $50 \mu \mathrm{g} \mathrm{ml} \mathrm{m}^{-1}$ naladixic acid, respectively. Bacterial suspensions were autoclaved for $15 \mathrm{~min}$ to prepare HK-bacteria. Final concentrations of live and HK-bacteria were equivalent to $10^{8} \mathrm{cfu} \mathrm{ml}^{-1}$ unless otherwise stated. Beakers, $50 \mathrm{ml}$, containing $20 \mathrm{ml}$ of the bacterial suspension were shaken at $170 \mathrm{rpm}$ in a water bath at $27^{\circ} \mathrm{C}$ until the oxygen concentration reached a steady state (about $15 \mathrm{~min}$ ).

\section{Plant suspension cells}

Tobacco (Nicotiana tabacum cv. Hicks) and potato (Solanum tuberosum cv. Kennebec) suspension cells were initiated, maintained and prepared for bioassays as previously described [1]. The oxygen uptake response was measured in $20 \mathrm{ml}$ of $0 \cdot 1 \mathrm{~g} \mathrm{ml}^{-1}$ suspension cells in $50 \mathrm{ml}$ beakers at $27^{\circ} \mathrm{C}$ and $200 \mathrm{rpm}$ for both potato and tobacco.

\section{Plant cell filtrate preparations}

Plant cell filtrates were prepared from 5 day old potato suspension cells or 2 to 3 day old tobacco cells (data not shown). Cells were collected onto Miracloth (Calbiochem Corp., LaJolla, CA, U.S.A.), washed and resuspended in $50 \mathrm{~mm}$ MES buffer, $\mathrm{pH} 6 \cdot 0$, to a concentration of $0.5 \mathrm{~g}$ $\mathrm{ml}^{-1}$. A portion of the cells were autoclaved for $20 \mathrm{~min}$ and poured through Miracloth. The residue was collected and resuspended in an equal volume of MES buffer (cell residue fraction). The filtrate was passed through a glass microfiber membrane followed by sterile filtration through a $0 \cdot 2 \mu \mathrm{m}$ nylon filter (cell filtrate fraction).

Another portion of the cell suspension $\left(0.5 \mathrm{~g} \mathrm{ml}^{-1}\right)$ was incubated in assay buffer for $3 \mathrm{~h}$ in a shaking water bath at $27^{\circ} \mathrm{C}$ and $200 \mathrm{rpm}$. Cells were removed from the medium by filtration through Miracloth, a glass microfiber membrane, and a $0.2 \mu \mathrm{m}$ nylon filter as above (washed cell filtrate fraction).

\section{Autoclaved leaf filtrate}

Tobacco and potato plants were grown in a greenhouse with $12 \mathrm{~h}$ light cycle at $21-27^{\circ} \mathrm{C}$. Leaf tissue with midribs and veins removed was ground in liquid nitrogen and resuspended in $50 \mathrm{~mm}$ MES, pH 6.0 to a final concentration of $0.5 \mathrm{~g} \mathrm{ml}^{-1}$. The suspension was autoclaved, cooled, and centrifuged at $8000 \mathrm{~g}$ for $20 \mathrm{~min}$ to remove cell debris. The autoclaved filtrate was sterile filtered as described above.

\section{Oxygen uptake measurements}

Oxygen electrodes (Microelectrodes Inc., Londonderry, NH, U.S.A.), data acquisition hardware and software (National Instruments Corp., Austin, TX, U.S.A.) were used as previously described [1]. Oxygen electrodes were soaked in 1\% tergazyme (Alconox, Inc., New York, NY, U.S.A.), rinsed with deionized water, and calibrated to $100 \%$ oxygen in aerated buffer in a water bath shaker maintained at $27^{\circ} \mathrm{C}$. The multi-electrode apparatus enabled the simultaneous monitoring of oxygen uptake rates in several beakers simultaneously while allowing continuous shaking and aeration of cells. The basic concept underlying this technique is that changes in the rate of oxygen uptake result in a change in the oxygen concentration. Based on calibration tests, at any given oxygen concentration in the buffer, the rate of oxygen flux from the air is known and should equal the oxygen uptake flux by the bacterial and/or plant cells [1].

\section{Active oxygen}

ROS production was monitored with the luminol dependent chemiluminescence assay as previously described [10]. Bacteria were added to beakers with autoclaved plant filtrate in assay buffer (175 mM mannitol, $0.5 \mathrm{~mm}$ $\mathrm{CaCl}_{2}, 0.5 \mathrm{~mm} \mathrm{~K}_{2} \mathrm{SO}_{4}$, and $0.5 \mathrm{~mm} \mathrm{MES,} \mathrm{pH} \mathrm{6.1).} \mathrm{At}$ 5 min time intervals, $0.4 \mathrm{ml}$ samples were removed from the beakers and assayed in a LKB 1251 luminometer (Bad Wildbad, Germany). Luminol (80 $\mu \mathrm{M}$ final concentration in $1 \mathrm{M} \mathrm{NaPO} 4, \mathrm{pH} 7)$ and horseradish peroxidase $(6 \mu \mathrm{g}$ $\mathrm{ml}^{-1}$ final concentration in deionized water) were automatically added and mixed into each sample in the dark 


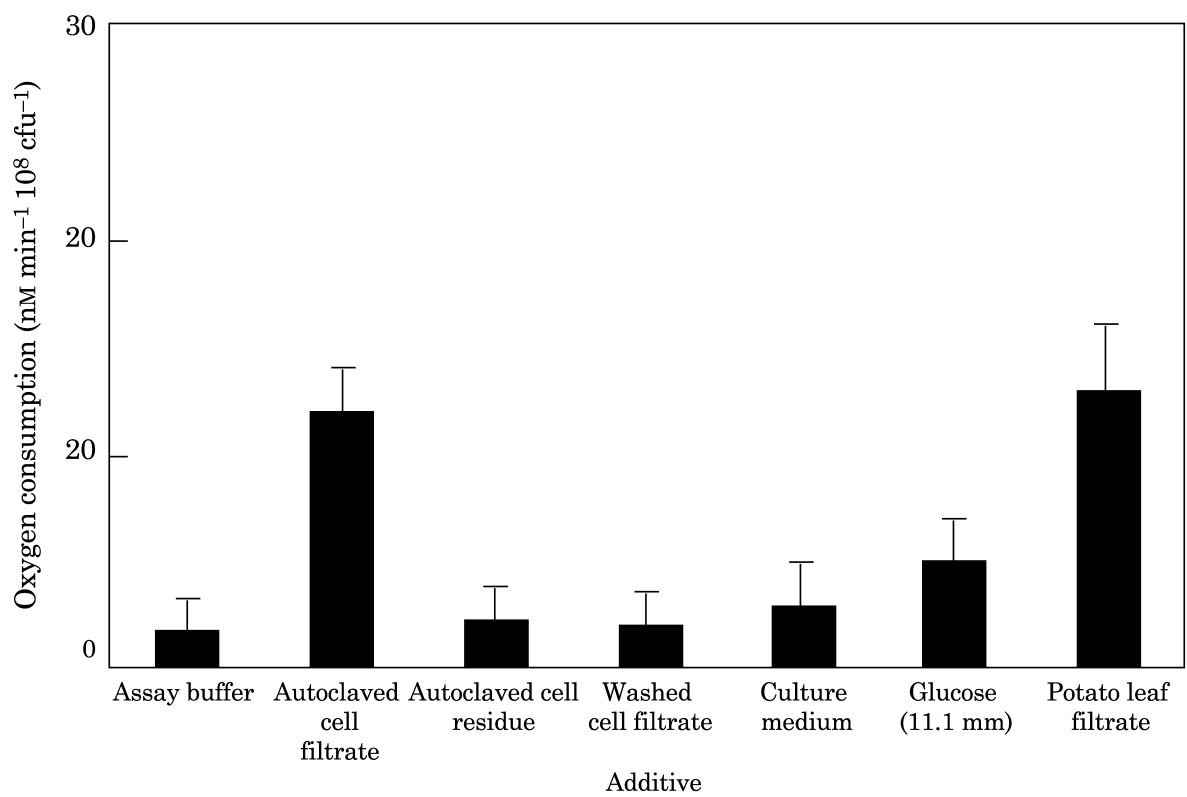

FIG. 1. Oxygen uptake by Pseudomonas syringae pv. syringae cells treated with various fractions of potato cells. Beakers of bacteria

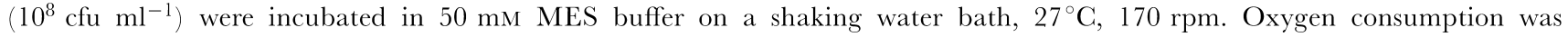
monitored with oxygen electrodes as described in Materials and Methods. Various plant cell suspension fractions, described in Materials and Methods, were added at a final dilution equivalent to $0.1 \mathrm{~g} \mathrm{ml}^{-1}$. The treatments consisted of: assay buffer (no treatment), autoclaved suspension cells divided into filtrate and residue, assay buffer in which cells had been incubated $3 \mathrm{~h}$, culture medium used to grow potato cells, glucose, and a potato leaf extract. The rate of oxygen consumption after 20 min, at which time $90 \%$ of the change has occurred is reported here for comparison of the treatments. Error bars represent one standard deviation from the mean.

and chemiluminescence immediately and continuously measured.

\section{RESULTS}

The oxygen uptake rate of suspensions of $P$. syringae pv. syringae increased significantly upon addition of certain plant cell or tissue extracts. The basal respiratory rate for $10^{8} \mathrm{cfu} \mathrm{ml}^{-1}$ bacteria was routinely $2 \mathrm{nM} \mathrm{min}^{-1}$ $10^{8} \mathrm{cfu}^{-1}$ in assay buffer. Addition of filtrate from washed autoclaved potato (Fig. 1) or tobacco (data not shown) cells caused an increase of about six- to seven-fold to approximately $12 \mathrm{nM} \min ^{-1} 10^{8} \mathrm{cfu}^{-1}$. Treatment with the autoclaved cell residue, washed cell filtrate, or plant tissue culture medium had little effect. Addition of $0.2 \%$ glucose $(11.1 \mathrm{mM})$ increased oxygen consumption by two- to three-fold, greater concentrations of glucose had no increased effect. Filtrates from potato (Fig. 1) and tobacco (not shown) leaves, which had been first ground with liquid nitrogen and then autoclaved, also elicited an oxygen uptake response from the bacteria.

Increased oxygen consumption was observed for several different bacteria including $P$. syringae pv. syringae, $P$. putida WT, $P$. putida $\mathrm{J} 1-\mathrm{M}$, and $R$. solanacearum when treated with autoclaved potato cell filtrate (Fig. 2). All bacteria responded with an immediate and rapid increase in

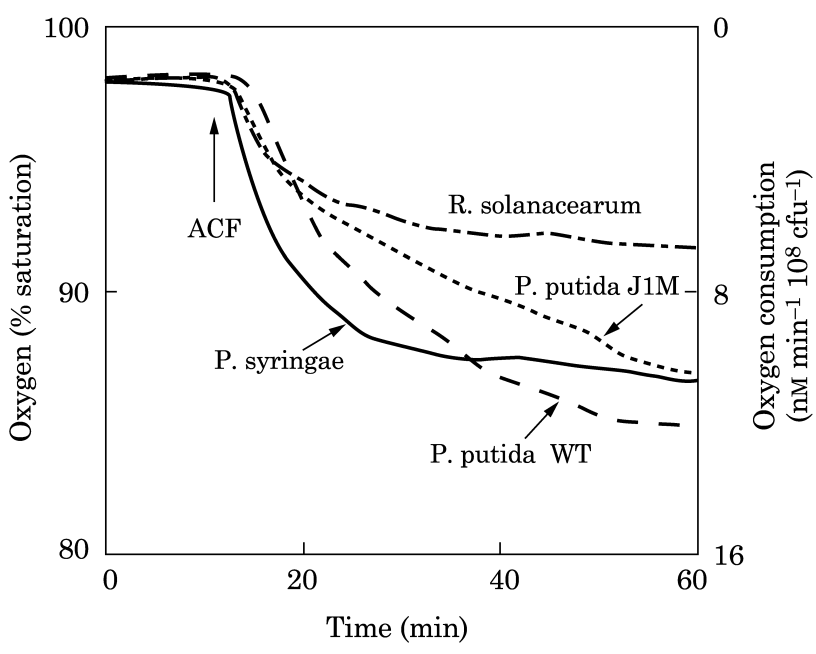

FIG. 2. Oxygen uptake of bacteria treated with potato filtrate. Bacteria $\left(10^{8} \mathrm{cfu} \mathrm{ml}^{-1}\right)$ were incubated in $50 \mathrm{mM}$ MES buffer and treated with autoclaved cell filtrate $(\mathrm{ACF})\left(0 \cdot 1 \mathrm{~g} \mathrm{ml}^{-1}\right.$ equivalent), added at the arrow. Oxygen consumption was monitored with electrodes as described in Materials and Methods.

oxygen consumption within 3-4 min after addition of the cell filtrate. $P$. syringae and $R$. solanacearum appeared to reach a new higher steady state while $P$. putida isolates continued to steadily increase their rate of oxygen consumption. Bacterial multiplication was not detected 
(a)

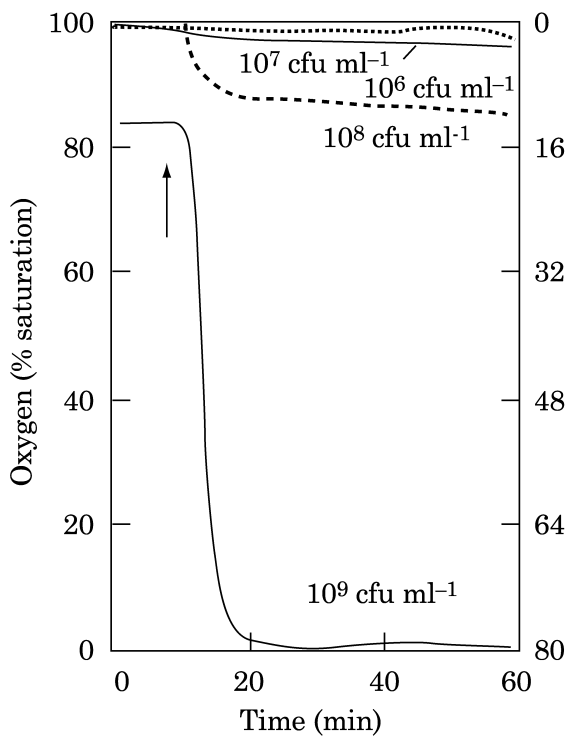

(b)

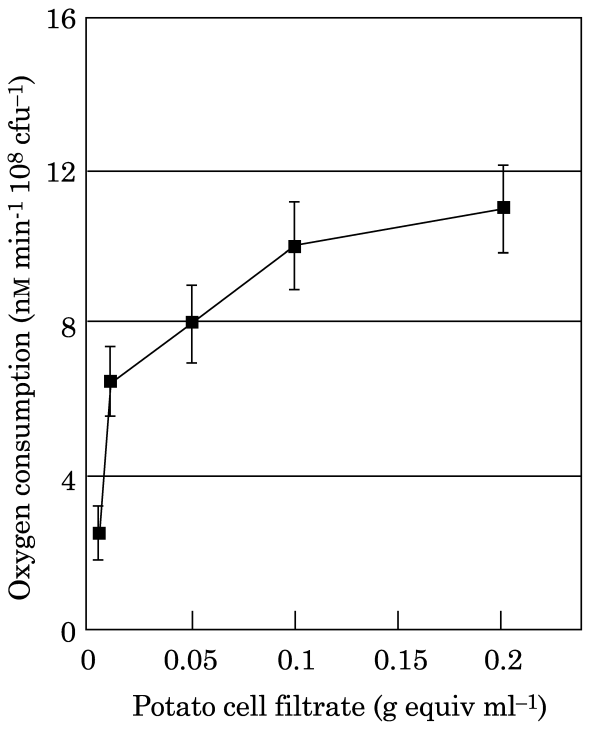

FIG. 3. Effect of varying amounts of bacteria and potato extract on the oxygen uptake response by bacteria. (a) Concentrations of P. syringae pv. syringae ranging from $10^{6}$ to $10^{9} \mathrm{cfu} \mathrm{m}^{-1}$ were treated with autoclaved potato cell filtrate $\left(0 \cdot 1 \mathrm{~g} \mathrm{ml}{ }^{-1} \mathrm{equivalent}\right)$, added at the arrow. (b) P. syringae pv. syringae $\left(10^{8} \mathrm{cfu} \mathrm{ml}^{-1}\right)$ was treated with autoclaved potato cell filtrate ranging from $0 \cdot 005$ to $0 \cdot 2 \mathrm{~g} \mathrm{ml}^{-1}$ equivalents. Oxygen concentration was monitored by oxygen electrode.

during the first 15-30 min after addition of plant extracts. After this period, multiplication was minimal for the first $2 \mathrm{~h}$ and could not account for the increased rates observed.

P. syringae pv. syringae at $10^{6}-10^{9} \mathrm{cfu} \mathrm{ml}^{-1}$ were treated with potato autoclaved cell filtrate and the oxygen uptake response was found to increase with increasing bacterial concentration [Fig. 3(a)]. Under the current assay conditions, it was difficult to detect an increase in oxygen consumption at concentrations less than $10^{7} \mathrm{cfu} \mathrm{ml}^{-1}$. The response of $10^{8} \mathrm{cfu} \mathrm{ml}^{-1}$ bacteria was a seven-fold increase in oxygen consumption over basal respiration while $10^{9} \mathrm{cfu} \mathrm{ml}^{-1}$ rapidly depleted the oxygen in the media within a few minutes. Results were similar with $R$. solanacearum (data not shown).

$P$. syringae pv. syringae at $10^{8} \mathrm{cfu} \mathrm{m}^{-1}$ was treated with varying concentrations of potato filtrate equivalent to 0.005-0.2 $\mathrm{g} \mathrm{ml}^{-1}$ of cells [Fig. 3(b)]. Both of the lowest concentrations of filtrate stimulated a rapid increase in oxygen uptake before leveling off at a higher rate of oxygen uptake than the basal rate. Filtrates equivalent to concentrations of $0 \cdot 05-0.2 \mathrm{~g}$ cells $\mathrm{ml}^{-1}$ stimulated a rapid increase in oxygen uptake followed by a much more gradual increase. The oxygen uptake response appeared to be nearly saturated at $0 \cdot 1 \mathrm{~g}$ equiv. $\mathrm{ml}^{-1}$ filtrate. Bacterial multiplication over the experimental time period was insignificant.

To help determine the sources of the oxygen uptake response, bacterial suspensions were pretreated with KCN (1 mM), a respiratory inhibitor of certain bacterial cytochromes, or DPI $(10 \mu \mathrm{M})$, a plant and animal
NADPH oxidase inhibitor (Fig. 4). DPI had no effect on the oxygen uptake response to potato ACF, suggesting that NADPH oxidase is not involved in the response. The $1 \mathrm{~mm}$ KCN completely inhibited the response suggesting that cytochrome oxidase of the bacterial respiratory chain may be involved.

The contribution of the bacterial oxygen uptake response to the combined plant/bacterial oxygen uptake response was estimated using streptomycin treated bacterial cells [Fig. 5(a)]. Streptomycin $\left(200 \mu \mathrm{g} \mathrm{ml}^{-1}\right)$ was added to $P$. syringae $\mathrm{pv}$. syringae $\left(10^{8} \mathrm{cfu} \mathrm{ml}^{-1}\right)$ suspensions for different periods before adding the potato ACF. The bacterial oxygen uptake response was inhibited by $60 \%$ after $15 \mathrm{~min}$ preincubation and about $85 \%$ after 30, 60 and $120 \mathrm{~min}$. Potato cells were pretreated with streptomycin followed by the addition of $10^{8} \mathrm{cfu} \mathrm{ml}^{-1}$ $P$. syringae pv. syringae that were also pretreated with streptomycin [Fig. 5(b)]. The streptomycin inhibited the initial oxygen uptake response by about $10 \%$ when compared to potato cells exposed to bacteria without preincubation with streptomycin. The streptomycin completely inhibited the later, more gradual increases in oxygen consumption. Pretreatment of potato cells with streptomycin had no effect on the plant oxygen uptake response to heat-killed bacteria.

$\mathrm{K}-252$, a protein kinase inhibitor, has been previously shown to significantly inhibit the plant cell oxygen uptake response [3]. This inhibitor had no effect on the bacterial oxygen uptake response to potato ACF [Fig. 6(a)]. When $\mathrm{K}-252(1.6 \mu \mathrm{M})$ was added to potato cells followed by addition of heat-killed $P$. syringae pv. syringae, there was a 


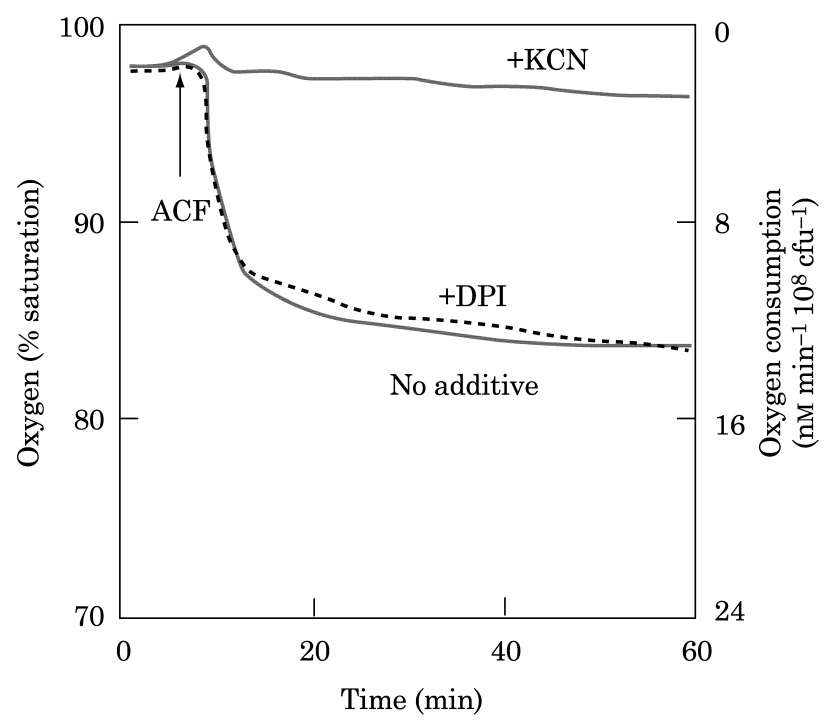

FIG. 4. Effect of KCN and DPI on the bacterial oxygen uptake response. $P$. syringae pv. syringae $\left(10^{8} \mathrm{cfu} \mathrm{ml}^{-1}\right)$ was treated with buffer, KCN $(1 \mathrm{mM})$ or DPI $(10 \mu \mathrm{M})$. Autoclaved potato plant cell filtrate (ACF) was added at the arrow. Oxygen concentration was monitored by electrode as described in Materials and Methods.

total inhibition of the oxygen uptake response of the plant cells [Fig. 6(b)]. Pretreatment of potato cells with K-252 inhibited the oxygen uptake response to viable $P$. syringae pv. syringae by approximately $70 \%$. These data, in concert with the streptomycin experiments, suggest that as much as $15-30 \%$ of the co-suspension oxygen uptake response is due to bacterial oxygen uptake response.

\section{DISCUSSION}

This report demonstrates that bacteria, upon contact with plant cells or plant components, respond with an increase in oxygen consumption. The plant component which elicits the bacterial response appears to be to released upon autoclaving of the plant cells or tissue, suggesting that it is either intracellular and/or closely attached to the cell wall. Several bacteria increased oxygen uptake as much as 10-fold within 10-20 min after treatment with autoclaved plant cell filtrate (Fig. 2). The amplitude of the oxygen uptake response increased with either bacterial concentration or elicitor concentration until saturation occurred (Fig. 3). KCN (Fig. 4) inhibited the oxygen uptake response suggesting the involvement of bacterial respiration [11]; DPI did not affect the response suggesting that NADPH oxidase is not involved. Unlike plant responses in which increased oxygen uptake is associated with accumulation of active oxygen, the bacterial response had no detectable levels of active oxygen accumulation.

The use of two inhibitors allowed insight into the origins of the oxygen uptake response that occurs when
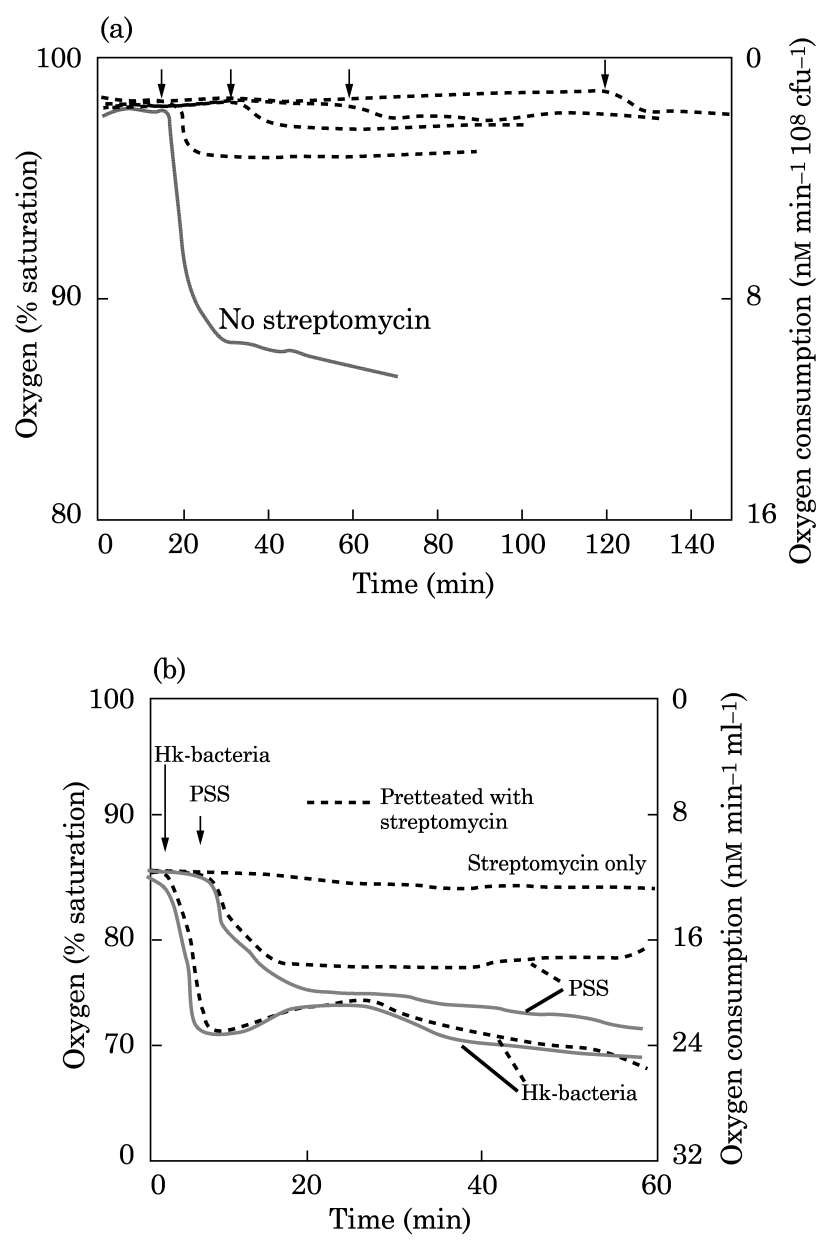

FIG. 5. Effect of streptomycin on the oxygen uptake response of bacteria and plant/bacteria interactions. (a) $P$. syringae pv. syringae $\left(10^{8} \mathrm{cfu} \mathrm{ml}^{-1}\right)$ was pretreated with streptomycin $\left(200 \mu \mathrm{g} \mathrm{ml}^{-1}\right)$ for $0,15,30,60$, and $120 \mathrm{~min}$ before addition of autoclaved plant cell filtrate $\left(0 \cdot 1 \mathrm{~g} \mathrm{ml}^{-1}\right.$ equivalent), added at the arrows. (b) Potato cells $\left(0.1 \mathrm{~g} \mathrm{ml}^{-1}\right)$ were incubated in buffer or pretreated with streptomycin, $200 \mu \mathrm{g} \mathrm{ml}{ }^{-1}$, with additions of $P$. syringae pv. syringae (Pss) or HK-bacteria. Oxygen concentration was monitored by oxygen electrode.

live plant suspension cells and bacterial cells come into contact. K-252, a protein kinase inhibitor that almost completely inhibits the plant oxygen uptake response, did not affect the oxygen uptake response of bacteria [Fig. 5(a)]. Streptomycin reduced the oxygen uptake response after $30 \mathrm{~min}$ pretreatment of the bacteria [Fig. 6(a)] but did not affect the plant oxygen uptake response [Fig. 6(b)]. In suspensions of $10^{8} \mathrm{cfu} \mathrm{ml}^{-1}$ bacteria and $0 \cdot 1 \mathrm{~g} \mathrm{ml}^{-1}$ plant cells about $10-30 \%$ of the increased oxygen consumption appears to be the result of the bacteria and the remainder from the plant cells. This was an unexpected result since the bacteria are composed of less than $1 \%$ of the total cell mass present.

Because of the magnitude of the oxygen flux, it is likely that bacterial respiration is involved. Bacteria have several cytochromes $\left(o, d\right.$, and $\left.a_{1}\right)$ which can act as terminal 
(a)

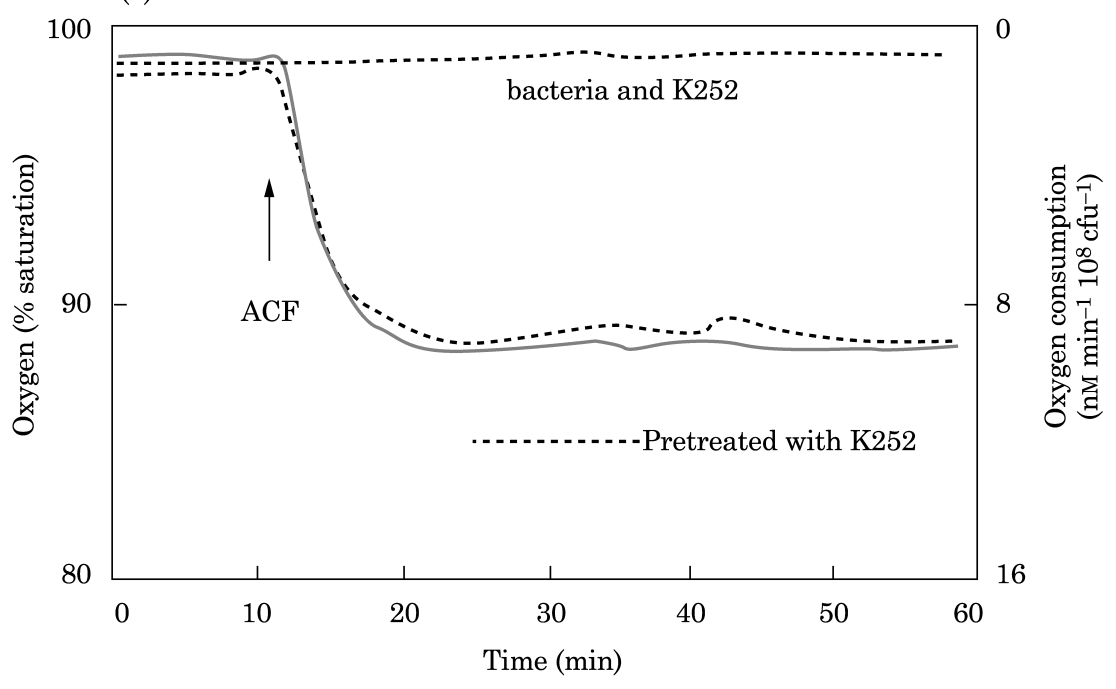

(b)

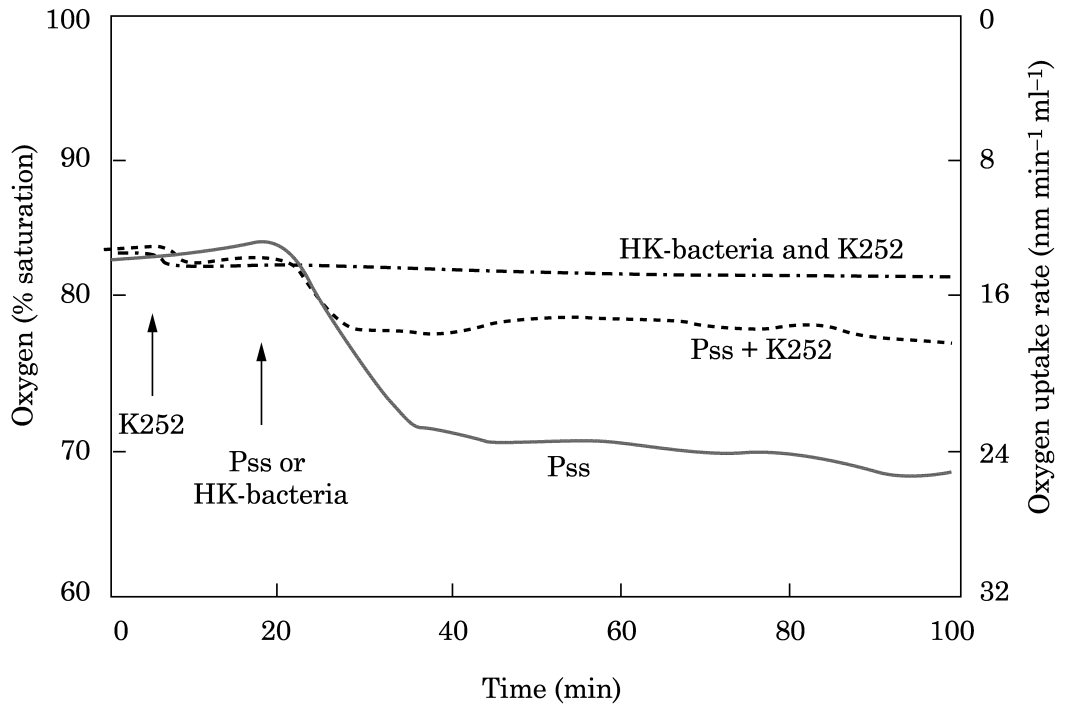

F IG. 6. Effect of K-252 on the oxygen uptake response of bacteria and plant/bacteria interactions. (a) P. syringae pv. syringae (10 $0^{8}$ cfu $\left.\mathrm{ml}^{-1}\right)$ was pretreated with $\mathrm{K}-252(1.6 \mu \mathrm{M}) 15 \mathrm{~min}$ before addition of buffer or autoclaved plant cell filtrate $\left(\mathrm{ACF}, 0 \cdot 1 \mathrm{~g} \mathrm{ml}{ }^{-1}\right.$ equivalent). (b) Potato cells $\left(0.1 \mathrm{~g} \mathrm{ml}^{-1}\right)$ were pretreated with buffer or $\mathrm{K}-252(1.6 \mu \mathrm{M})$ with additions of $P$. syringae pv. syringae

(Pss) or HK-bacteria. Oxygen concentration was monitored by electrode as described in Materials and Methods.

oxidases and transfer electrons to oxygen $[6,7]$. P. syringae pv. syringae contains cytochrome $d$ which accommodates the majority of electron flow during log phase growth $[13,16]$. P. putida appears to have a different cytochrome makeup including cytochrome $\mathrm{d}$ which is able to function under lower concentrations of oxygen [15]. This difference could contribute to the ability of $P$. putida isolates to continue increasing oxygen uptake at lower concentrations of oxygen.

Unlike the plant oxygen uptake response, there was no concurrent measurable $\mathrm{H}_{2} \mathrm{O}_{2}$ accumulation by the bacteria, even when lower bacterial concentrations were used to avoid $\mathrm{H}_{2} \mathrm{O}_{2}$-scavenging [2]. It is still feasible and probable that this increased oxygen uptake was leading to increased superoxide and hydrogen peroxide $[4,9,14]$ production, however, it may not accumulate to allow measurement.

The oxygen uptake response observed here by bacterial cell suspensions was substantial, representing as much as a six- to seven-fold increase in bacterial oxygen uptake over basal respiration. The oxygen consumption by bacterial concentrations greater than $10^{8} \mathrm{cfu} \mathrm{ml}^{-1}$ bacteria could affect oxygen availability to plant cells in cell suspension and possibly leaf infiltration experiments. The magnitude of the response generated under these in vitro conditions may be greater than would be 
encountered in tissue since all of the bacterial cells encountered a relatively high concentration of the plant elicitor. However, bacteria in the area of plant cells with leaky membranes and water soaking could feasibly encounter a similar situation.

(C) 2001 US Government

\section{REFERENCES}

1. Baker CJ, Mock NM, Deahl K, Domek J. 1997. Monitoring the rate of oxygen consumption in plant cell suspensions. Plant Cell, Tissue and Organ Culture 51: $111-117$.

2. Baker CJ, Orlandi EW, Anderson AJ. 1997. Oxygen metabolism in plant cell culture/bacteria interactions: role of bacterial concentration and $\mathrm{H}_{2} \mathrm{O}_{2}$-scavenging in survival under biological and artificial oxidative stress. Physiological and Molecular Plant Pathology 51: 401-415.

3. Baker CJ, Orlandi EW, Deahl K. 2000. Oxygen metabolism in plant/bacteria interactions: characterization of the oxygen uptake response of plant suspension cells. Physiological and Molecular Plant Pathology 57: 159-167.

4. Bestwick CS, Brown IR, Bennett MHR, Mansfield JW. 1997. Localization of hydrogen peroxide accumulation during the hypersensitive reaction of lettuce cells to Pseudomonas syringae pv. phaseolicola. The Plant Cell 9: 209-221.

5. Bolwell GP, Butt VS, Davies DR, Zimmerlin A. 1995. The origin of the oxidative burst in plants. Free Radical Research 23: 517-532.

6. Haddock BA, Jones GW. 1977. Bacterial respiration. Bacteriological Reviews 41: 47-99.

7. Ingledew WJ, Poole RK. 1984. The respiratory chains of Escherichia coli. Microbiological Reviews 48: 222-271.
8. Katsuwon J, Anderson AJ. 1992. Characterization of catalase activities in a root-colonizing isolate of Pseudomonas putida. Canadian Fournal of Microbiology 38: 1026-1032.

9. Nagata K, Yu H, Nishikawa M, Kashiba M, Nakamura A, Sato EF, Tamura T, Inoue M. 1998. Helicobacter pylori generates superoxide radicals and modulates nitric oxide metabolism. The Fournal of Biological Chemistry 273: 14071-14073.

10. Orlandi EW, Hutcheson SW, Baker GJ. 1992. Early physiological responses associated with race-specific recognition in soybean leaf tissue and cell suspensions treated with Pseudomonas syringae pv. glycinea. Physiological and Molecular Plant Pathology 40: 173-180.

11. Pudek MR, Bragg PD. 1974. Inhibition by cyanide of the respiratory chain oxidases of Escherichia coli. Archives of Biochemistry and Biophysics 164: 682-693.

12. Robertson D, Davies DR, Gemish G, Jupe SG, Bolwell GP. 1995. Rapid changes in oxidative metabolism as a consequence of elicitor treatment of suspension-cultured cells of French bean (Phaseolus vulgaris L.). Plant Molecular Biology 27: 59-67.

13. Sands DG, Gleason FH, Hildebrand DG. 1967. Cytochromes of Pseudomonas syringae. Fournal of Bacteriology 94: 1785-1786.

14. Shvinka JE, Toma MK, Galinina NI, Skards IV, Viesturs UE. 1979. Production of superoxide radicals during bacterial respiration. Journal of General Microbiology 113: 377-382.

15. Sweet WJ, Peterson JA. 1978. Changes in cytochrome content and electron transport patterns in Pseudomonas putida as a function of growth phase. Fournal of Bacteriology 133: 217-224.

16. Zannoni D. 1982. Cytochrome $b$ type oxidases in the respiratory chains of the phytopathogenic fluorescent bacteria Pseudomonas cichorii and Pseudomonas aptata. Archives of Microbiology 133: 267-273. 